One is reminded of the observatory which once existed on top of the great gate of Trinity at Cambridge. Many plans were made for the reorganisation of the observatory during the first half of the nineteenth century, but nothing was accomplished until Kaiser prevailed upon Parliament to grant money for a new observatory, which was built in 1860 . Kaiser combined his chair of astronomy with the office of 'verificator of nautical instruments', and devoted the observatory to meridian work, so that, as reorganised, it resembled Greenwich. Recently, an astrophysical department has been added. The present staff of the Observatory of Leyden is very strong, and includes de Sitter, Hertzsprung, Woltjer and Oort. The tercentenary brochure enumerates the many instruments now to be found in the Observatory, and we may echo Prof. de Sitter's concluding remark that the Observatory of Leyden is well equipped to enter upon its fourth century.

\section{Meteor Shower of October 9}

A FrNE display of shooting stars was observed at many places in western Europe on the night of Monday, October 9, between the hours of 6.30 p.m. and 10 p.m. The spectacle caused great alarm in many country districts of Portugal, people taking refuge in the churches. A similar display occurred on October 9, 1926, and it is associated with Giacobini's comet, which has a period of about $6 \frac{3}{4}$ years. In 1900, when the comet was discovered, the nearest approach of the two orbits was about $5 \frac{1}{2}$ million miles, but perturbations sufficiently disturbed the orbit of the comet to make it intersect that of the earth in 1926 , though the point of intersection was about two months in front of the comet, and the comet itself was therefore about 77 million miles from it on October 9 of that year. This year the comet is estimated to have been only about one million miles distant from the earth, and a brilliant shower of shooting stars was the result.

\section{Integral Right-Angled Triangles}

THE solutions of the equation $a^{2}+b^{2}=c^{2}$ in integral numbers given in Sir Flinders Petrie's letter in NATURE of September 9, are all contained in the formula

$$
\{2 n(n+p)\}^{2}+\left\{(n+p)^{2}-n^{2}\right\}^{2}=\left\{(n+p)^{2}+n^{2}\right\}^{2}
$$

for $n=1,2,3,4,5$, horizontally and $p=1,2,3,4$, down the page. The most general solution of the equation $a^{2}+b^{2}=c^{2}$ in integral numbers is given by

$$
a=2 \lambda f g, b=\lambda\left(f^{2}-g^{2}\right), c=\lambda\left(f^{2}+g^{2}\right)
$$

for integral values of $f, g, \lambda$. Sir Maurice Amos, and several other correspondents, have addressed letters to the Editor pointing out that Sir Flinders Petrie's statements are incomplete. In the first place, solutions certainly exist not contained in the table; for example,

$$
a=12, b=9, c=15 .
$$

Again, Mr. J. H. Awbery, of Teddington, points out correctly that, when the table is extended to include all solutions of one and two digits, their number is
30 , of which 16 are sets without common factor, and not 19 as stated by the author. Mr. A. F. Dufton, of Garston, points out that there are fifty solutions of $a^{2}+b^{2}=c^{2}$ for which $c$ contains fewer than three figures; but some of these, of course, are not included in Sir Flinders Petrie's table. Further, Mr. H. J. Woodall, of Stockport, points out that a large range of integral solutions of the equation $a^{2}+b^{2}=c^{2}$ was tabulated by the late Lt.-Col. A. J. C. Cunningham. This table, however, only mentions the cases where $c$ is a prime number, whereas Sir Flinders Petrie's table includes many solutions where $c$ is composite.

\section{Sites of Scientific Interest in East Africa}

Representations supported by the leading scientific societies of Great Britain, including the British Association, the Royal Society, and the Royal Anthropological Institute, have been made to the Government of Kenya, asking for the protection of the area in which are the fossil beds of Kanam and Kanjera. The area in question is situated at the north-east corner of Victoria Nyanza. The fossil beds include those on Rusinga Island at the mouth of Kavirondo Bay, which constitute one, and the richest, of the three deposits of Miocene age in Kenya. It was in the Kanam and Kanjera Pleistocene deposits that Dr. L. S. B. Leakey discovered the fossil human remains, which were examined at a conference of leading palæontologists, geologists, anatomists and archæologists at Cambridge in March last (see NATuRE, 131, 427 and $477 ; 1932$ ). It is now announced that the Government of Kenya has taken steps to exclude the site from the area for which exclusive prospecting licences have been invited, and to preserve it as a protected area under the Ancient Monuments Preservation Ordinance, 1927. Earlier in the year, in response to similar representations addressed to the Government of Tanganyika Territory, an order was issued under the Preservation of Archæological Objects Ordinance, 1929, declaring the area containing the fossil beds in which were found the remains of Oldoway man a protected area. Dr. Leakey, who has been chiefly responsible for bringing the matter to the notice of the respective Governments, is to be congratulated on a result assuring the preservation of these areas, which are of the greatest importance for future research in the archæology and palæontology of East Africa and for the history of the development of man.

AN exhibition of specimens, including human remains, found by Dr. Leakey at Kanam and Kanjera is on view at the British Museum (Natural History) until October 30. Since the conference at Cambridge, to which reference is made above, accepted the human remains as presenting no characters incompatible with their inclusion in the type Homo sapiens, and their assignment to Lower and Middle Pleistocene age respectively, Dr. Leakey has been engaged in further comparative study of the specimens. His conclusions, it is now understood, confirm his previous views. The Kanjera skulls, he holds, belong to Homo sapiens, and as being of Middle Pleistocene 
age, far antedate any of the previously known examples of Homo sapiens, to which dates not earlier than the end of the Ice Age have been assigned. On the other hand, he holds that the Kanam fragment of mandible, being of early Pleistocene age, is of the same high order of antiquity as Java, Peking and Piltdown man. Dr. Leakey will submit his conclusions to the Royal Anthropological Institute in a lecture on "The Status of the Kanjera Skulls and the Kanam Mandible" to be delivered on October 20 at 5.30 p.m., when Prof. Elliot Smith will take the chair.

\section{Romano-British Pottery at Colchester}

FURTHER details of the interesting finds of Roman potters' kilns at Colchester are given in an article in the Times of October 10 which marks the close of the Colchester Excavation Committee's work for the season. Since comparatively little is known about the detail of the manufacture of 'Samian' pottery in Britain, the find is of considerable importance. A series of eight kilns was discovered. Four of the kilns, widely spaced, had been used for jugs, mortaria and other vessels in coarse buff ware. The second four kilns were concentrated in a narrow area surrounded by a retaining wall and buried 5-8 ft. deep beneath a mass of material in which the numerous fragments of 'Samian' moulds and ware made it evident beyond question that this was the place of manufacture of the 'Samian' ware. The material in the largest kiln, $14 \mathrm{ft}$. long, had been fused by overfiring. Not only were the two types, the old-style British and the 'Samian', mass production articles, found where they had been made, side by side, but also the stamps of the 'Samian' ware bore well-known names of potters whose factories are known in eastern Gaul and Germany. These are repeated on the colour-coated 'Castor' ware, decorated with applied hunting scenes, which was also made at Colchester. These stamps and the similarities of form and moulds linking them up with examples of known date from the Continent, afford sure criteria for fixing a date, which is corroborated by the find of a coin of Marcus Aurelius, at about A.D. 180 to 200 .

\section{Significance of Anthropological Studies in Modern Civil-} isation

A coorse of eleven public lectures on "The Study of Man" will be delivered at University College in the University of London during the coming session. The lectures will have a topical interest in a somewhat unusual sense. Their aim will be to present aspects of the subject-matter of the science of anthropology as a study of the methods by which man in the past and also backward peoples have approached the problems of life; but more especially they will suggest the practical bearing of the principles governing human actions and reactions, revealed by anthropological studies, in the solution of like problems which arise in modern civilisation. The opening lecture, on "The Practical Value of Human Studies", will be delivered by Mr. F. J. Richards, honorary lecturer in Indian archæology.
Prof. Charles Singer will follow on "The Develop. ment of the Study of Man". The remaining lecturers will be: Prof. C. B. Fawcett, on "Geographical Factors in the Study of Man" ; Dr. R. E. M. Wheeler, on "Early Civilisation and Economics"; Dr. Margaret Murray, on "Religion and Ritual in the Study of Man"; Prof. B. Ashmole, on "The Place of Art in the Study of Man"; Mr. S. R. K. Glanville, on "The Eastern Origin of Western Civilisation" ; Dr. R. E. M. Wheeler, on "Race and History in Ancient Europe" ; Dr. L. W. G. Malcolm, on "Africa, Past and Present"; Mr. A. M. Hocart, on "The South Seas, the Organisation of Peoples" ; and Mr. K. de B. Codrington, on "India, the Village as a Social Unit". The lectures will be delivered at University College, Gower Street, W.C., on each Monday in term at 5.30 p.m., beginning on Monday next, October 16. The chair at the first lecture will be taken by the Provost, Dr. Allen Mawer.

\section{Chemistry, Philosophy and Food Values}

IT is evidence of vigour of both mind and body when a man who can say that he saw the Great Eastern upon the stocks, before she sailed west to lay the first Atlantic cable, is able to deliver an address of an hour's duration which will hold an audience largely composed of students. Prof. Henry E. Armstrong is, however, known in the world of chemistry as one whom the years pass lightly by. His mind is as intellectually alert, critical and unrepentant to-day as at any time during his long career. The address which he gave at the opening of the College of the Pharmaceutical Society on October 4 contains passages of caustic comment mixed with others of no less delightful charm, which illustrate as much his philosophy of life as his outlook upon his own profession. It makes stimulating reading. Although some may smile as here and there they detect echoes of opinions which the author has made peculiarly his own, yet the address emphasised a truth that can never be overstated: that it is essential that philosophical theorising shall proceed side by side with the practical experiments of the laboratory, without which there can be no sure progress.

Some flowers from Prof. Armstrong's collection may be preserved. His first chemical appointment he chronicles in the words:- "I mounted the professional dunghill in the autumn of 1870 at the London Institution, Finsbury Circus". Of Bentley, whose services to botany were mainly in the realm of classification, he says :- "He was certainly a character, but he knew his plants, an accusation that can be brought against few botanists to-day", and upon the trend of modern chemical thought towards mathematics and away from the laboratory, his comment is:- "Of late years the clerical mind has again ruled us; chemistry has suffered a neophilogistic outburst. Oxygen has gone out of fashion, its place taken by a beautiful myth, as elusive as phlogiston, the hydrogen ion, a creation of Leipzig journalism, never born of science, but only guesswork". He is critical of the fads of the researcher 